\title{
Associations of soft flooring materials in free stalls with milk yield, clinical mastitis, teat lesions, and removal of dairy cows
}

\author{
L. E. Ruud, ${ }^{* 1}$ K. E. Bøe, ${ }^{*}$ and O. Østerås $\dagger$ \\ *Department of Animal- and Aquacultural Sciences, Norwegian University of Life Sciences, N-1432 Ås, Norway \\ †Department of Production Animal Clinical Sciences, Norwegian School of Veterinary Science, 0033 Oslo, Norway
}

\begin{abstract}
The objective was to test if there was an association between free-stall base softness and milk yield, incidence of clinical mastitis (CM), teat lesions, and removal of cows. In a questionnaire sent to 1,923 dairy farms presumed to be using free-stall housing, farmers were asked for information regarding housing and stall base; for example, the year of installation and the product name or brand of their mats or mattresses. This information was merged with data for milk yield, CM, teat lesions, and removal of cows extracted from the Norwegian Dairy Herd Recording System for the years after installation of mats or mattresses. After exclusion of invalid contributions, the data set consisted of 29,326 lactations for milk yield distributed over 363 free-stalled herds in Norway. The farms were stratified into 5 categories according to the softness of the stall surface measured as millimeter impact of a sphere with a diameter of $120 \mathrm{~mm}$ at $2-\mathrm{kN}$ load: $1=$ concrete, softness of $0 \mathrm{~mm} ; 2=$ rubber, softness of 1 to $8 \mathrm{~mm} ; 3=$ soft mats, softness of 9 to $16 \mathrm{~mm} ; 4=$ multilayer mats, softness of 17 to $24 \mathrm{~mm}$; and $5=$ mattresses, softness over $24 \mathrm{~mm}$. Lactation curves were estimated as modified Wood's lactation curves using test-day data and mixed models with repeated measurements, adjusting for days in milk, parity, and softness of free-stall flooring. Herds on concrete free-stall bases yielded 6,727 \pm $146 \mathrm{~kg}$ of milk from 5 to 305 days in milk. In comparison, herds showed a decrease of $0.3 \%$ on rubber, an increase of $2.4 \%$ on soft mats, an increase of $4.5 \%$ on multilayer mats, and an increase of $3.9 \%$ on mattresses. Compared with concrete, the hazard ratio (HR) of CM was less on rubber, multilayer mats, and mattresses $[\mathrm{HR}=0.89(0.79-0.99), 0.85(0.73-0.996)$, and 0.80 (0.73-0.88), respectively]. Compared with concrete, the HR of teat lesions was less on rubber, soft mats, multilayer mats, and mattresses $[\mathrm{HR}=0.41(0.26-0.65)$, $0.33(0.24-0.44), 0.12(0.04-0.38)$, and $0.47(0.33-0.67)$,
\end{abstract}

Received September 21, 2009.

Accepted December 18, 2009.

${ }^{1}$ Corresponding author: ler@geno.no respectively]. The HR of removal of cows was less on mattresses compared with concrete, rubber, soft mats, and multilayer mats, with $\mathrm{HR}=0.90(0.84-0.97), 0.88$ $(0.80-0.97), 0.86 \quad(0.80-0.93)$, and $0.85(0.76-0.95)$, respectively. A soft free-stall base contributed significantly to increased milk yield and fewer incidences of $\mathrm{CM}$, teat lesions, and removal of cows.

Key words: free-stall base softness, milk yield, clinical mastitis, teat lesion

\section{INTRODUCTION}

Lying surfaces for dairy cows should provide thermal comfort and softness, be durable, and have sufficient friction to allow cows to stand up and lie down without slipping. They should help in keeping the cows clean and healthy and minimize daily labor requirements (Chaplin et al., 2000). Lying is an important and highly prioritized behavior in cattle, and normal lying time in free stalls is 8 to $16 \mathrm{~h} / \mathrm{d}$ (Tucker and Weary, 2004). The duration could be influenced, among other factors, by housing and bedding (Krohn and Munksgaard, 1993). In a preference test setup, Wander (1974) found that dairy cows preferred the softness of 10 to $15 \mathrm{~cm}$ of sawdust in free stalls. Dairy cows have a strong preference for soft bedding materials, such as soft mattresses (Herlin, 1997; Rushen et al., 2001). Furthermore, lying time increases when softer flooring materials are introduced (Rushen et al., 2001). Interestingly, Major Bramley, the inventor of the free stall, introduced soft mats in the first free stalls in 1957 (Bramley, 1962). To provide a simple, physical method for measuring stall-base softness, Nilsson (1988) expressed softness as millimeter impact of a sphere (diameter $=100 \mathrm{~mm}$ at $2-\mathrm{kN}$ load), a method later adapted to a sphere with the diameter of a cow's knee (diameter $=120 \mathrm{~mm}$ ) by ADAS, United Kingdom (Dumelow, 1995) and applied by others; for example, Deutsche Landwirtschafts-Gesellschaft (DLG, 2009) in its testing procedures for mats and mattresses.

Milk yield is significantly decreased by clinical mastitis (CM), and all precautions that can reduce the incidence of $\mathrm{CM}$ are positive. It is important to maintain clean stall surfaces and environments that sustain the 
defense systems of the body (unbroken skin, immune system) to resist disease pathogenesis. Soft mats stay cleaner than concrete (Herlin, 1997), and clean stall surfaces are associated with a lesser rate of IMI (Schreiner and Ruegg, 2003). Furthermore, soft mats have a heatinsulating capacity (Nilsson, 1988), protecting the udder from being cooled. Ewbank (1968) demonstrated that cold flooring in stalls is associated with an increase in SCC. There was a reduction by almost $50 \%$ in the SCC in herds with rubber mats compared with concrete (Østerås and Lund, 1988), and Valde et al. (1997) found the incidence rate of mastitis reduced by $14 \%$ in herds with rubber mats compared with concrete floors. Teat lesions are painful for the animals, and the number of even minor injuries is associated with a greater SCC (Geishauser et al., 1999) and greater incidence of mastitis (Elbers et al., 1998). Apart from Østerås and Lund (1988) finding a greater incidence of teat lesions in tie stalls with concrete flooring compared with rubber mats, documentation on the effects of free-stall base softness on teat lesions is scarce.

Data on culling or removal of cows are used as an indicator of how the production environment influences the cows. The reasons for cows being removed from a herd are complex and range from disease to forming part of normal recruitment for the herd (Hadley et al., 2006). The most important reasons for removal in Holstein cows are reproductive disorders, udder disorders (including mastitis and teat injuries), and locomotor disorders (Beaudeau et al., 2000). Thomsen et al. (2007) described concrete-floored stalls as a risk factor for "loser cows;" that is, cows that often end up dying or being culled.

The main hypothesis was that soft free-stall bases would contribute to an increase in milk yield and a lowered incidence of mastitis and teat lesions. It was reasonable to make the hypothesis that a soft free-stall base, which is associated with a long lying time, would provide vulnerable cows a better opportunity for rest and recuperation, hence reducing the risk of removal. The objective was to test if there was an association between free-stall base softness and milk yield, incidence of CM, teat lesions, and removal of cows.

\section{MATERIALS AND METHODS}

\section{Herds in the Study}

Based on lists from a former survey (Sogstad et al., 2005), a questionnaire was sent to all known free-stall and loose-housed herds in Norway $(\mathrm{n}=1,923)$ during the winter of 2004 to 2005 . In the questionnaire, the farmers were asked about the type of flooring material in their free stalls, the brand of their mats or mattresses, if installed, and the year of installation, as well as some housing aspects. A total of 704 farmers responded to the questionnaire, giving a response rate of $36.6 \%$. Of these, 601 had a free-stall system and were included in the study. Herds with unknown year of installation of mat or mattresses $(\mathrm{n}=7)$, with more than one particular kind of free-stall base $(\mathrm{n}=87)$, with a barn newer than the mats or mattresses $(\mathrm{n}=4)$, with mats or mattresses older than 1998 if not concrete $(\mathrm{n}=$ 102), with a barn itself built before $1980(\mathrm{n}=16)$, and with mats and mattresses installed in $2005(\mathrm{n}=7)$ were excluded. Herds not registered in the Norwegian Dairy Herd Recording System (NDHRS) were also excluded $(\mathrm{n}=15)$. The final data set consisted of 363 herds.

\section{Free-Stall Base Softness}

Deutsche Landwirtschafts-Gesellschaft (DLG) is a German organization that conducts thorough tests of commercial farming equipment, including mats and mattresses. With information about the brand name of free-stall base available in the questionnaire, the results from the DLG test reports (DLG, 2009) were used for categorization of softness (millimeter impact). Hence, softness was not measured on-farm. In the DLG test reports, softness was measured as millimeter impact of a sphere (diameter $=120 \mathrm{~mm}$ ) at 2-kN load. Stall-base softness for each farm was categorized into one of the following 5 classes of softness: $1=$ concrete, softness of $0 \mathrm{~mm}$, hard free-stall base made of concrete without any cushion; 2 = rubber, softness of 1 to $8 \mathrm{~mm}$, free stalls typically equipped with compact rubber mats; $3=$ soft mats, mats with softness of 9 to $16 \mathrm{~mm}$, for example, light "comfort mats" or rubber mats with rubber studs underneath them contributing to softness; $4=$ multilayer mats, multilayer or other mats with softness of 17 to $24 \mathrm{~mm}$; and $5=$ mattresses, soft mattresses with softness over $24 \mathrm{~mm}$. No other information about stall design or use of bedding was sought.

\section{Cows in the Study}

Data from each individual cow were extracted from the NDHRS database for the year after installation of mats or mattresses. The following data were collected: test day, kilograms of milk on test day, kilograms of concentrate fed on test day, information about disease on test day, parity, calving day, day of removal from the herd, and all disease treatments including day of treatment. The number of days from installation of new mats or mattresses and calving was calculated. 
Lactations with calving before August 2001 and after July 2005 were excluded. All lactations starting with an abortion or with calving before, or in, the installation year were also excluded.

\section{Milk Yield}

Milk yields are weighed monthly on the farms and then reported to NDHRS. Test days with a daily milk yield $<7 \mathrm{~kg}$ were deleted, as well as one recording $>80$ $\mathrm{kg}$. Also, test days before DIM $=5$ and test days after DIM $=330$ were deleted. The milk-yield data set contained 226,686 test-day observations from 29,326 different lactations using 17,528 different cows and 363 different herds.

\section{CM, Teat Lesions, and Cows Removed}

In Norway, all medical treatments of animals must be done by a veterinarian, including mastitis treatments, and are then reported into the NDHRS database (Østerås et al., 2007). All recordings of CM, defined according to the International Dairy Federation (IDF, 1999), teat lesions, and cow removal were extracted from this database. A teat lesion was defined as acquired teat trauma or wound in conjunction with the skin, or an injury disturbing the milk stream, of a severity subject to veterinary treatments. All cows removed from the original herd in which they were registered in the NDHRS database, including cows sold to another herd or to slaughter, were considered as cows removed. The observation period for each lactation started $15 \mathrm{~d}$ before calving and ended either on the day of removal or $15 \mathrm{~d}$ before the next calving. The data set for the study of CM, teat lesions, and cows removed comprises 32,167 different lactations by 19,216 different cows within the 363 herds. Lactations with observation periods longer than $542 \mathrm{~d}$ ( $5 \%$ of the lactations) and one lactation with an obvious error in the removal date were excluded. After excluding these extremely long lactations, there were 31,779 lactations left, from 19,011 different cows and 363 different herds. These recordings were merged with a data set of unique lactations for each cow, and all observations of CM between start and end of the observation period were included. Only the first observation of CM was included in a survival analysis. This data set was merged with the information about stall-base softness from each farm. The same procedure was used for the teat lesions. Finally, a new data set was made $(\mathrm{n}=7,923)$ with all primary cases of $\mathrm{CM}$, merged with all the secondary cases of CM. Secondary cases of CM were sought at $100 \mathrm{~d}$ after the primary case of $\mathrm{CM}$. The first $4 \mathrm{~d}$ after a primary case were counted as retreatment of the primary case of CM and, thus, such cases were excluded as a secondary case. The removal day and reason registered in the NDHRS database were merged with the lactation information. The observation period used in the survival analysis for removal was from calving to removal, censored for 200 DIM or, in cases of early calving, at $15 \mathrm{~d}$ before next calving. Cows listed as dead or condemned were cows registered as dead or condemned in the NDHRS database as cause for removal.

\section{Statistical Analysis}

Milk Yield. To estimate the lactation curve, a modified model according to Wilmink (1987) was fitted, adapted according to the lactation curve presented by Wood (1967). These milk-yield data were fitted into a mixed model using the PROC MIXED procedure in SAS (SAS version 9.1. from SAS Institute Inc., Cary, NC) with test-day milk yield as the dependent variable. The traits DIM, InDIM, whether the cow was diseased on the test day, free-stall base softness class, test-day year, and test-day month were used as fixed variables. The final model included interaction between DIM, lnDIM, and softness class. The mixed models were analyzed with repeated measurements applying autoregressive correlation type 1 matrix $\operatorname{AR}(1)$ and were fitted separately for parity $1,2,3$, and $>3$. There was no backward or forward exclusion in the model construction. The model estimates were fed into a spreadsheet to construct the milk curve per softness class and to estimate the model-based 5 to 305 DIM total mean milk yields as the sum of estimated test-day milk yield. Milk yield was calculated separately per parity. Finally, to check the overall fit of the model-based results, the mean and standard deviation for each lactation month (each 30-d interval) were estimated from the raw data within each softness class.

The general model used for estimating $Y$ was

$$
\begin{aligned}
Y_{m y} & =\beta_{0}+\beta_{1} \times \mathrm{DIM}+\beta_{2} \times \operatorname{lnDIM}+\beta_{3} \times \mathrm{DIM} \\
& \times \operatorname{soft}_{x}+\beta_{4} \times \operatorname{lnDIM} \times \operatorname{soft}_{x}+\operatorname{soft}_{x}+\beta_{5} \\
& \times \text { test-year }_{x}+\beta_{6} \times \text { test-month } \\
x & +Z_{l}+e,
\end{aligned}
$$

where $Y_{m y}=$ test-day milk yield, $\beta_{0}=$ intercept, $\beta_{i}=$ estimated coefficient, soft $_{x}=$ association of softness of bedding material, $Z_{l}=$ random effect of lactation, and $e=$ random error.

Confidence interval for 305-DIM milk yield based on model estimates was established by applying estimates with standard error using simulation with @RISK, version 5.5.0, (Palisade Corporation, Ithaca, NY). 
Table 1. Description of study herds $(\mathrm{n}=363$ herds $)$ stratified according to free-stall softness $( \pm \mathrm{SD})$

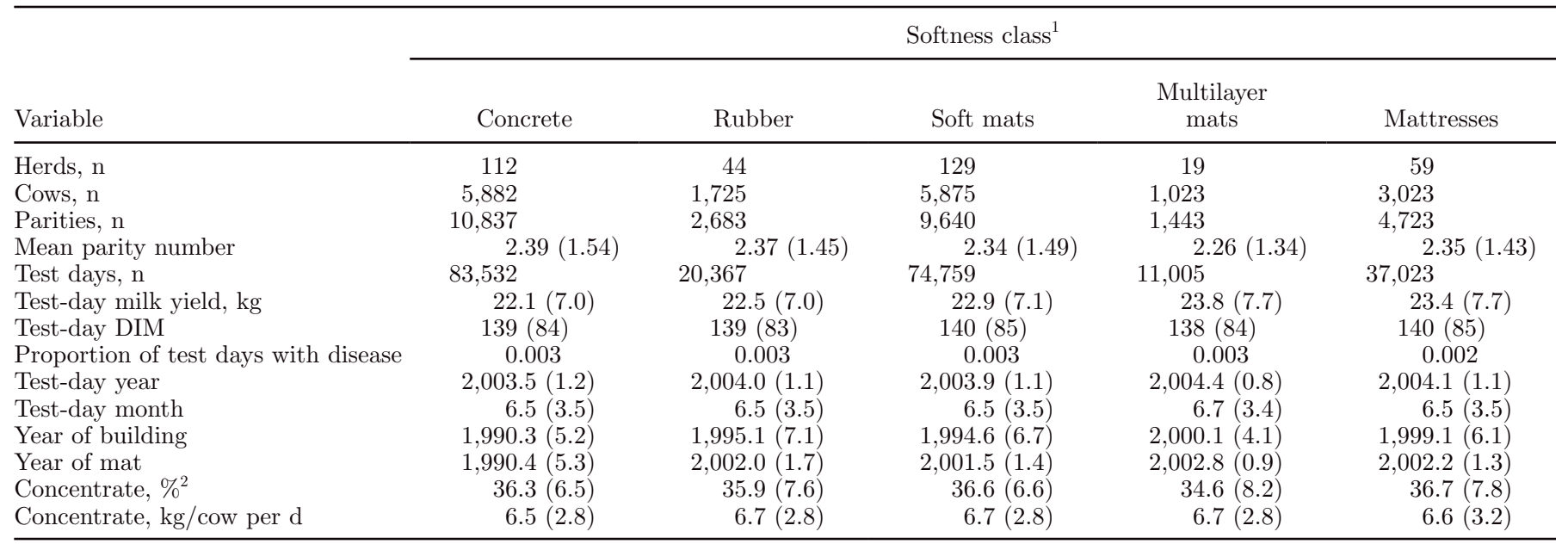

${ }^{1}$ Softness measured as millimeter impact of a sphere $($ diameter $=120 \mathrm{~mm})$ at 2 -kN load. Concrete $=0 \mathrm{~mm}$ impact; rubber $=1$ to $8 \mathrm{~mm}$ impact; soft mats $=9$ to $16 \mathrm{~mm}$ impact; multilayer mats $=17$ to $24 \mathrm{~mm}$ impact; mattresses $=$ impact $>24 \mathrm{~mm}$.

${ }^{2}$ Concentrate as percentage of total energy intake on herd level.

Mastitis, Teat Lesions, and Removal. The health data were analyzed using the survival analysis PROC LIFETEST and PROC PHREG in SAS (SAS version 9.1. from SAS Institute Inc.). The hazard ratio (HR) for a cow to develop CM or a teat lesion or for removal was estimated using Cox regression analyses (Cox, 1972) with the general hazard function $[h$ for $i$ th individual in $k$ th herd (stratum)]:

$$
h_{i k}(t)=\lambda_{i 0}(t) \exp \left(\beta_{i k}\right),
$$

where $\beta$ in this particular study was defined with the fixed covariates parity $(1,2,3$, and $>3)$, softness class, and calving year; $t$ was time from start of observation to event (CM, teat lesion, or removal); and $\lambda$ was the baseline hazard. All variance estimate survival models were analyzed with robust sandwich methods using ties $=$ exact and herd as the id variable (Lin and Wei, 1989).

Data observations were censored at end of lactation, at next calving, or at 305 DIM if there was no calving or removal. Concrete, rubber, soft mats, multilayer mats, and mattresses were included as covariates and adjusted for parity $1,2,3$, and $>3$ and recording year as fixed effects. The survival analyses were analyzed for the period from $15 \mathrm{~d}$ before calving until primary case of disease or removal occurred. The period from the primary case of CM to a secondary case of CM was analyzed in a separate model. Separate models were made for CM, teat lesions, and removal. If significant, the estimates were adjusted for year of calving. The significance level was $P \leq 0.05$.

\section{RESULTS}

\section{Herd Characteristics and Free-Stall Flooring}

The average herd size during 2005 for the herds was $26.5 \pm 14.7$ (mean $\pm \mathrm{SD}$ ) standardized cow-years within a range of 6.4 to 92.2 (cow-year $=$ sum of number of days within a herd from first calving to culling within 1 yr, divided by 365, corresponding to mean number of cows in the herd at any time). Norwegian Red dairy breed was used as the main breed (98.8\% of the cows). The feed ration used on the farms, calculated on an energy basis, consisted of $37.1 \%$ concentrate, $45.3 \%$ grass silage, $12.6 \%$ pasture, and $5.0 \%$ other feedstuff. The most common free-stall bases were concrete and soft mats (Table 1).

\section{Milk Yield}

Multilayer mats and mattresses were associated with greater milk yield compared with concrete floorings and rubber mats. Soft mats were associated with a milk yield greater than that with concrete and rubber mats but less than that with multilayer mats and mattresses. Multilayer mats and mattresses were associated with a milk yield 1.1 to $5.8 \%$ greater than that for concrete stall bases. The mean and standard deviation of test-day milk yield, DIM, test-day year, and test-day month are presented in Table 1. In Table 2, the raw mean test-day milk-yield data, distributed in 30-d intervals, are presented. Table 3 presents the estimated parameters for the model-based milk curve within parities, and Table 
Table 2. Mean test-day milk yield $(\mathrm{kg} / \mathrm{d})$ from the raw data in free-stalled dairy herds $(\mathrm{n}=363$ herds) within each free-stall base softness class distributed in 30-d intervals $( \pm \mathrm{SD})$

\begin{tabular}{|c|c|c|c|c|c|c|c|c|c|c|}
\hline \multirow{2}{*}{$\begin{array}{l}\text { Lactation } \\
\text { period } \\
\text { (DIM) }\end{array}$} & \multicolumn{10}{|c|}{ Softness class ${ }^{1}$} \\
\hline & \multicolumn{2}{|c|}{ Concrete } & \multicolumn{2}{|c|}{ Rubber } & \multicolumn{2}{|c|}{ Soft mats } & \multicolumn{2}{|c|}{ Multilayer mats } & \multicolumn{2}{|c|}{ Mattresses } \\
\hline $5-30$ & 8,694 & $25.43(6.77)$ & 2,064 & $25.72(6.24)$ & 7,667 & $25.83(6.56)$ & 1,122 & $26.42(6.88)$ & 3,821 & $26.00(7.00)$ \\
\hline $31-60$ & 10,022 & $27.11(6.81)$ & 2,503 & $27.69(6.54)$ & 8,896 & $28.14(6.75)$ & 1,316 & $29.15(7.41)$ & 4,419 & $28.85(7.43)$ \\
\hline 61-90 & 9,578 & $26.03(6.48)$ & 2,352 & $26.53(6.36)$ & 8,614 & $27.01(6.48)$ & 1,266 & $28.10(7.27)$ & 4,210 & $27.94(7.09)$ \\
\hline $151-180$ & 8,524 & $21.17(5.32)$ & 2,154 & $21.31(5.51)$ & 7,674 & $21.95(5.47)$ & 1,159 & $22.91(6.34)$ & 3,724 & $22.63(6.09)$ \\
\hline $181-210$ & 8,170 & $19.60(5.15)$ & 2,002 & $19.77(5.41)$ & 7,261 & $20.28(5.22)$ & 1,062 & $21.27(5.89)$ & 3,644 & $20.73(5.85)$ \\
\hline $211-240$ & 7,599 & $17.91(4.89)$ & 1,858 & $18.10(5.20)$ & 6,782 & $18.56(5.00)$ & 971 & $19.58(5.63)$ & 3,323 & $18.81(5.74)$ \\
\hline $241-270$ & 6,424 & $16.06(4.63)$ & 1,556 & $16.40(4.92)$ & 5,888 & $16.76(4.74)$ & 835 & $17.45(5.22)$ & 2,845 & $16.95(5.41)$ \\
\hline $271-300$ & 4,105 & $14.67(4.36)$ & 940 & $15.10(4.89)$ & 3,815 & $15.27(4.57)$ & 515 & $15.66(5.14)$ & 1,911 & $15.76(5.14)$ \\
\hline $301-330$ & 1,924 & $14.17(4.28)$ & 410 & $14.48(4.58)$ & 1,662 & $14.75(4.53)$ & 249 & $15.04(5.15)$ & 938 & $14.84(4.85)$ \\
\hline
\end{tabular}

${ }^{1}$ Softness measured as millimeter impact of a sphere (diameter $=120 \mathrm{~mm}$ ) at 2 -kN load. Concrete $=0 \mathrm{~mm}$ impact; rubber $=1$ to $8 \mathrm{~mm}$ impact; soft mats $=9$ to $16 \mathrm{~mm}$ impact; multilayer mats $=17$ to $24 \mathrm{~mm}$ impact; mattresses $=$ impact $>24 \mathrm{~mm}$.

4 present the estimated 5 to 305 DIM milk yield in kilograms, based on these model estimates distributed on parity and softness class. All parameter estimates for all parities in Table 3 concerning softness class were significant $(P<0.001)$. In the total population, $36.5 \%$ of the animals were in parity $1,26.6 \%$ were in parity 2 , $17.3 \%$ were in parity 3 , and $19.6 \%$ were above parity
3. No difference in distribution of animals regarding parity was found between softness classes.

\section{CM}

There were 4,309 (13.6\%) lactations with at least one case of CM before 305 DIM (Table 5). Adjusted for

Table 3. The model-based estimates (SE) according to mixed models estimating the test-day milk yield (kg/d) for dairy cows in free stalls ( $\mathrm{n}$ $=363$ herds) distributed by parity ${ }^{1}$

\begin{tabular}{|c|c|c|c|c|c|}
\hline \multirow[b]{2}{*}{ Variable } & \multirow[b]{2}{*}{ Class } & \multicolumn{4}{|c|}{ Parity } \\
\hline & & 1 & 2 & 3 & $>3$ \\
\hline Intercept & & $10.195(0.348)$ & $14.390(0.468)$ & $13.771(0.618)$ & $14.560(0.561)$ \\
\hline \multirow[t]{2}{*}{ Ill on test day } & No & $4.049(0.189)$ & $5.244(0.237)$ & $5.407(0.300)$ & $5.219(0.237)$ \\
\hline & Yes & 0 & 0 & 0 & 0 \\
\hline DIM & & $-0.067(0.0009)$ & $-0.103(0.001)$ & $-0.120(0.002)$ & $-0.120(0.002)$ \\
\hline $\operatorname{lnDIM}$ & & $3.517(0.077)$ & $4.239(0.107)$ & $5.161(0.146)$ & $4.944(0.141)$ \\
\hline \multirow[t]{5}{*}{ Softness class $^{2}$} & Concrete & $2.012(0.320)$ & $2.908(0.447)$ & $4.734(0.596)$ & $1.345(0.572)$ \\
\hline & Rubber & $1.669(0.459)$ & $1.880(0.608)$ & $5.325(0.815)$ & $1.007(0.823)$ \\
\hline & Soft mats & $1.057(0.325)$ & $1.731(0.451)$ & $2.578(0.608)$ & $0.498(0.591)$ \\
\hline & Multilayer mats & $1.361(0.556)$ & $0.312(0.767)$ & $1.094(0.998)$ & $-2.125(1.064)$ \\
\hline & Mattresses & 0 & 0 & 0 & 0 \\
\hline \multirow[t]{5}{*}{ DIM $\times$ softness class } & Concrete & $0.005(0.001)$ & $0.017(0.002)$ & $0.021(0.002)$ & $0.013(0.002)$ \\
\hline & Rubber & $0.003(0.002)$ & $0.014(0.002)$ & $0.021(0.003)$ & $0.009(0.003)$ \\
\hline & Soft mats & $0.003(0.001)$ & $0.011(0.002)$ & $0.013(0.002)$ & $0.004(0.002)$ \\
\hline & Multilayer mats & $-0.0002(0.002)$ & $0.0005(0.003)$ & $0.006(0.004)$ & $0.006(0.004)$ \\
\hline & Mattresses & 0 & 0 & 0 & 0 \\
\hline \multirow[t]{5}{*}{$\operatorname{lnDIM} \times$ softness class } & Concrete & $-0.723(0.092)$ & $-1.376(0.130)$ & $-1.883(0.175)$ & $-0.936(0.169)$ \\
\hline & Rubber & $-0.573(0.133)$ & $-1.107(0.177)$ & $-2.057(0.240)$ & $-0.734(0.244)$ \\
\hline & Soft mats & $-0.382(0.094)$ & $-0.803(0.131)$ & $-1.042(0.179)$ & $-0.332(0.174)$ \\
\hline & Multilayer mats & $-0.164(0.161)$ & $-0.004(0.223)$ & $-0.451(0.293)$ & $0.072(0.314)$ \\
\hline & Mattresses & 0 & 0 & 0 & 0 \\
\hline Random lactation, \% & & 3.5 & 2.5 & 2.2 & 2.0 \\
\hline Random error, $\%$ & & 96.5 & 97.5 & 97.8 & 98.0 \\
\hline
\end{tabular}

${ }^{1}$ Adjusted for DIM; lnDIM; cows ill on test day; softness class of free-stall base; interaction between DIM, lnDIM, and softness; and test-day year and test-day month. Estimates are adjusted to test-day year 2006 and month of December. Estimates for test-day year and test-day month are not shown. One model per parity $1,2,3$, and $>3$.

${ }^{2}$ Softness measured as millimeter impact of a sphere (diameter $=120 \mathrm{~mm}$ ) at 2-kN load. Concrete $=0 \mathrm{~mm}$ impact; rubber $=1$ to $8 \mathrm{~mm}$ impact; soft mats $=9$ to $16 \mathrm{~mm}$ impact; multilayer mats $=17$ to $24 \mathrm{~mm}$ impact; mattresses $=$ impact $>24 \mathrm{~mm}$. 
parity and calving year, there was less $\mathrm{CM}$ on rubber $[P<0.05 ; \mathrm{HR}=0.89(0.79-0.99)]$, multilayer mats $[P$ $<0.05 ; \mathrm{HR}=0.85(0.73-0.996)]$, and mattresses $[P<$ $0.001 ; \mathrm{HR}=0.80(0.73-0.88)]$ compared with concrete floors. The risk of CM was greater with soft mats $[P<$ $0.05 ; \mathrm{HR}=1.09(1.02-1.17)]$ compared with concrete and less with multilayer mats $[P<0.01 ; \mathrm{HR}=0.78$ $(0.67-0.91)]$ and mattresses $[P<0.001 ; \mathrm{HR}=0.73$ $(0.67-0.81)]$ versus soft mats. The risk of relapsing into $\mathrm{CM}$ within the same lactation was less on mattresses $(P<0.05)$ versus concrete floors, with $\mathrm{HR}=0.76$ (0.60-0.97). No other differences regarding new cases of $\mathrm{CM}$ between softness classes were found.

\section{Teat Lesions}

There were $323(1.0 \%)$ lactations with teat lesions before 305 DIM (Table 5). Adjusted for parity and calving year, the risk of teat lesions was less with rubber, soft mats, multilayer mats, and mattresses than with concrete free-stall bases (all with $P<0.001$ ), with HR $=0.41(0.26-0.65), \mathrm{HR}=0.33(0.24-0.44), \mathrm{HR}=0.12$ $(0.04-0.38)$, and HR $=0.47(0.33-0.67)$, respectively. Multilayer mats had a lesser HR [0.28 (0.09-0.93)] than did rubber $(P<0.05)$. No other differences in teat lesions between softness classes were found.

\section{Removal}

There were $7,656(24.1 \%)$ lactations ending with removal within 200 DIM (Table 5). The risk of removal was less with mattresses compared with concrete $(P<$ $0.01)$, rubber $(P<0.01)$, soft mats $(P<0.001)$, and multilayer mats $(P<0.01)$, with $\mathrm{HR}=0.90(0.84-0.97)$, $\mathrm{HR}=0.88(0.80-0.97), \mathrm{HR}=0.86(0.80-0.93)$, and $\mathrm{HR}=0.85(0.76-0.95)$, respectively. No other differences in removal between softness classes were found. Altogether, $296(0.9 \%)$ lactations ended in death or condemned meat at slaughter (Table 5). There was no difference in death or condemned meat between softness classes in raw data or in the total population. All softness classes except multilayer mats were close to significantly $(P<0.10)$ better than concrete. When analyzing only removed animals, concrete was a greater risk factor for death and condemned meat compared with all the other softness classes $(P<0.05)$, with HR $=1.30(1.02-1.67)$.

\section{DISCUSSION}

Softer floorings were, in general, associated with increased milk yield. In addition, softer floorings were 
Table 5. Health events (raw data) distributed on free-stall softness class $(\mathrm{n}=363$ free-stalled dairy herds)

\begin{tabular}{|c|c|c|c|c|c|}
\hline Softness class ${ }^{1}$ & Lactations, n & $\begin{array}{l}\text { With clinical } \\
\text { mastitis, n }(\%)^{2}\end{array}$ & $\begin{array}{c}\text { With teat } \\
\text { lesions, } \mathrm{n}(\%)^{2}\end{array}$ & $\begin{array}{l}\text { Removals, } \\
\mathrm{n}(\%)^{2}\end{array}$ & $\begin{array}{c}\text { Dead or } \\
\text { condemned, } \\
n(\%)^{2}\end{array}$ \\
\hline Concrete & 11,863 & 1,671 (14.1) & $203(1.7)$ & $2,862(24.1)$ & $127(1.1)$ \\
\hline Soft mats & 10,292 & $1,522(14.8)$ & $57(0.6)$ & $2,556(24.8)$ & $93(0.9)$ \\
\hline Multilayer mats & 1,564 & $178(11.4)$ & $4(0.3)$ & $390(24.9)$ & $14(0.9)$ \\
\hline Mattresses & 5,039 & $567(11.3)$ & $39(0.8)$ & $1,107(22.0)$ & $41(0.8)$ \\
\hline
\end{tabular}

${ }^{1}$ Softness measured as millimeter impact of a sphere (diameter $=120 \mathrm{~mm}$ ) at 2 -kN load. Concrete $=0 \mathrm{~mm}$ impact; rubber $=1$ to $8 \mathrm{~mm}$ impact; soft mats $=9$ to $16 \mathrm{~mm}$ impact; multilayer mats $=17$ to $24 \mathrm{~mm}$ impact; mattresses $=$ impact $>24 \mathrm{~mm}$.

${ }^{2}$ Percent of lactations.

generally associated with decreased incidence of CM, teat lesions, and removal.

\section{Milk Yield}

Earlier studies investigating the associations of stall flooring softness on milk yield used small populations and did not reveal significant associations (Chaplin et al., 2000; Rushen et al., 2001). Hence, this study was based on a questionnaire aimed at a large study population. In this study, test-day milk yield was used as demonstrated by Wilmink (1987) and estimated the shape of the lactation curves stratified by parity. The relative risk for $\mathrm{CM}$, teat lesions, and removal normally increases with parity, and hence, herd composition could influence raw data studies. However, this was corrected for, as models with repeated measurements will make the estimates as unbiased as possible owing to, for example, different parities and removal strategy. In an epidemiological study like this, diseases that are more frequent in one softness class, e.g., CM, teat lesions, or lameness, could influence milk yield, but such correlated associations have not been investigated. The milk yield estimated in Table 4 corresponds well with the milk yield raw data for all study herds in Tables 1 and 2 and with mean milk yield from the total population in the NDHRS database with $6,921 \mathrm{~kg}$ per cow year in 2008 (Tine rådgivning, 2009). According to our hypothesis, the greatest milk yield was expected on mattresses, but the milk yield found in this group was not consistently greater than that for multilayer mats (Table 4). As well as the softness itself, one could speculate that incidence of disease, group size, management routines, or the mattress group was less homogenous than other product groups and could play a role. According to the test reports from DLG (DLG, 2009), for example, soft mattresses have a greater tendency to be persistently compressed than harder stall surfaces, resulting in properties changing toward less softness.

\section{CM}

The risk of CM was less for rubber, multilayer mats, and mattresses versus concrete floors. This supports the findings of Valde et al. (1997), who found less CM in cows in free-stall housing with rubber mats compared with cows in concrete-floored stalls. In this study, we had no information about causal agents related to $\mathrm{CM}$, and the association was estimated on generic mastitis reported to the NDHRS database. Less hygienic housing conditions are a risk factor for CM (Elbers et al., 1998); soft surfaces stay cleaner (Herlin, 1997) and clean stalls are associated with a lower bacterial count on teat ends (Zdanowicz et al., 2004). However, the link to udder health is more unclear. Furthermore, the heat-insulating capacity of a product increases with softness of mats (Nilsson, 1988) and could play a role in preventing mastitis because "cold udders" have greater SCC (Ewbank, 1968). The insulation and other physical properties of the stall surface in relation to indoor temperature could influence lying behavior (Manninen et al., 2002). On soft mats, the risk of CM was greater than on concrete floors, but no such association could be seen with teat lesions. This suggests that there is sufficient traction on soft mats to avoid teat lesions. Practical experience has shown that permanent pits develop over time, especially on foam mats, under the pressure of cow claws, making the mat surfaces dirtier and influencing the incidence of CM. New cases of CM were more frequent on concrete floors than on the other surfaces in the present study, but no studies on new cases of CM with respect to free-stall base softness were found in the literature.

\section{Teat Lesions}

As a cow rises, it needs good traction against the floor. If the cow slips during rising, it will immediately try to get its feet under its body again, which often results in 
the cow tramping on its own teats (Krohn and Munksgaard, 1993). The low incidence of teat lesions found in all softness classes compared with concrete floors could be an association of improved traction rather than of softness itself, as indicated by Nilsson (1988). Lesser incidence rates of teat lesions on rubber mats compared with concrete floors were found by Østerås and Lund (1988). Interestingly, the incidence rate of teat lesions reported to NDHRS decreased from $2.7 \%$ in 2003 to $1.3 \%$ in 2008 (NCHS, 2009). This reduction might be a consequence of new regulations making multilayer mats or mattresses mandatory for all cows in Norway since 2006. The prevalence of concrete floors has been drastically reduced, and multilayer mats and mattresses have increased by the same order of magnitude (L. E. Ruud et al., unpublished data).

\section{Removal}

Associations of lesser risk of removal were identified for all soft free-stall bases compared with concrete floors. The reasons for cow removal from a herd are complex, ranging from diseases to being a part of normal recruitment to the herd (Hadley et al., 2006). Whether the lesser risk of removal on mattresses versus concrete floors found in this study was an effect of stall-base softness on cow longevity or differences in the farmers' attitudes or management requires more research.

\section{General Discussion}

Finding associations of stall-base softness with milk yield and health incidences was not a straightforward exercise because the associations investigated could be biased by feeding, season, breed, and herd composition, as well as other housing and management effects. One more ideal comparison would be to use the herd as its own control, comparing results before and after installation of mats and mattresses. Yet, change in stall surface often was associated with new buildings, change in ownership, season, and herd composition. Hence, a comparison within a farm could introduce even more bias. Age of building was different between softness classes, with concrete being older than rubber and soft mats, and barns with multilayer mats and mattresses being newer. Regarding the age of the stall surface itself, only concrete was older than the other softness classes. Year is, therefore, corrected for in the models. Amount and frequency of adding new bedding could in itself affect the stall-base softness (Wander, 1974). Even if there were no information about use of bedding, a field study in Norwegian free-stalled dairy herds (L. E. Ruud et al., unpublished data) revealed that only minor amounts of bedding were used $(0.6 \mathrm{~L}$ per free stall). It is reasonable to conclude that the actual use of bedding did not influence the results of this study. Sand or straw-bedded stalls are very uncommon in Norway because of the limited availability of such bedding materials.

\section{CONCLUSIONS}

A softer free-stall base was associated with greater milk yield and lesser incidence of $\mathrm{CM}$, teat lesions, and removal compared with harder stall surfaces. Concrete floors, especially, but also hard rubber mats, should be avoided as stall bases in free stalls because they were associated with lesser milk yield and greater incidence of CM, teat lesions, and removal. Soft floorings should clearly be selected in free stalls for dairy cows, especially when greater milk yield or a reduction in the incidence of CM, teat lesions, or removal of cows is the objective.

\section{ACKNOWLEDGMENTS}

The authors thank the participating farmers for their help and support. Access to the data was given by the Norwegian Dairy Herd Recording System (NDHRS) and the Norwegian Cattle Health Services (NCHS; for health data) in agreement number $3 / 2006$. The study was financially supported by grants from the Foundation for Research Levy on Agricultural Products (Fondet for forskningsavgift på landbruksprodukter), the Research Council of Norway (Norges forskningsråd), and Agricultural Agreement Research Fund (Forskningsmidler over jordbruksavtalen).

\section{REFERENCES}

Beaudeau, F., H. Seegers, V. Ducrocq, C. Fourichon, and N. Bareille. 2000. Effect of health disorders on culling in dairy cows: A review and a critical discussion. Ann. Zootech. 49:293-311.

Bramley, M. 1962. Kow Kubicles. Pages 69-73. Farm Buildings Association, Stowmarket, Suffolk, UK.

Chaplin, S. J., G. Tierney, C. Stockwell, D. N. Logue, and M. Kelly. 2000. An evaluation of mattresses and mats in two dairy units. Appl. Anim. Behav. Sci. 66:263-272.

Cox, D. R. 1972. Regression models and life-tables (with discussion). J. Royal Stat. Soc. Ser. B (Stat. Methodol.) 34:187-220.

DLG (Deutsche Landwirtschafts-Gesellschaft). 2009. Test reports for prefabricated mats and mattresses. http://www.dlg.org/de/ landwirtschaft/testzentrum/ pruefberichte/stalleinrichtungen.html Accessed June 10, 2009.

Dumelow, J. 1995. Testing cubicle mats for dairy cows. Agric. Eng. $50: 17-21$

Elbers, A. R. W., J. D. Miltenburg, D. de Lange, A. P. P. Crauwels, H. W. Barkema, and Y. T. Schukken. 1998. Risk factors for clinical mastitis in random sample of dairy herds from the southern part of the Netherlands. J. Dairy Sci. 81:420-426.

Ewbank, R. 1968. An experimental demonstration of the effect of surface cooling upon the health of the bovine mammary gland. Vet. Rec. 83:685-686. 
Geishauser, T., K. Querengässer, M. Mitschke, and A. Sorbiraj. 1999. Milk yield, somatic cell counts, and risk of removal from herd for dairy cows after covered teat canal injury. J. Dairy Sci. 82:14821488.

Hadley, G. L., C. A. Wolf, and S. B. Harsh. 2006. Dairy cattle culling patterns, explanations, and implications. J. Dairy Sci. 89:22862296.

Herlin, A. H. 1997. Comparison of lying area surfaces for dairy cows by preference, hygiene and lying down behaviour. Swed. J. Agric. Res. 27:189-196.

IDF (International Dairy Federation). 1999. Suggested interpretation of mastitis terminology. Bull. Int. Dairy Fed. Bulletin no. 338. International Dairy Federation, Brussels, Belgium.

Krohn, C. C., and L. Munksgaard. 1993. Behaviour of dairy cows kept in extensive (loose housing/pasture) or intensive (tie stall) environment. II. Lying and lying-down behaviour. Appl. Anim. Behav. Sci. 37:1-16.

Lin, D. Y., and L. J. Wei. 1989. The robust inference for the proportional hazards model. J. Am. Stat. Assoc. 84:1074-1078.

Manninen, E., A. M. de Passillé, J. Rushen, M. Norring, and H. Saloniemi. 2002. Preferences of dairy cows kept in unheated buildings for different kinds of cubicle flooring. Appl. Anim. Behav. Sci. 75:281-292.

NCHS (The Norwegian Cattle Health Services). 2009. Annual report 2008. http://storfehelse.tine.no Accessed June 10, 2009

Nilsson, C. 1988. Floors in animal houses. Dissertation. Report 61, LBT, Swedish University of Agricultural Sciences, Lund, Sweden.

Østerås, O., and A. Lund. 1988. Epidemiological analyses of the associations between bovine udder health and housing. Prev. Vet. Med. 6:79-90.

Østerås, O., H. Solbu, A. O. Refsdal, T. Roalkvam, O. Filseth, and A. Minsaas. 2007. Results and evaluation of thirty years of health recordings in Norwegian dairy cattle population. J. Dairy Sci. 90:4483-4497.

Rushen, J., A. M. de Passillé, D. B. Haley, E. Manninen, and H. Saloniemi. 2001. Using behavioral indicators and injury scores to assess the effect of stall flooring on cow comfort. Pages 716-723 in Livestock Environ. VI: Proc. 6th Int. Symp, Louisville, KY. Publication No. 701P0201, Am. Soc. Agric. Engineers, St. Joseph, MI.

Schreiner, D. A., and P. L. Ruegg. 2003. Relationship between udder and leg hygiene scores and subclinical mastitis. J. Dairy Sci 86:3460-3465.

Sogstad, Å. M., T. Fjeldaas, O. Østerås, and K. Plym Forshell. 2005. Prevalence of claw lesions in Norwegian dairy cattle housed in tie stalls and free stalls. Prev. Vet. Med. 70:191-209.

Thomsen, P. T., S. Østergaard, H. Houe, and J. T. Sørensen. 2007. Loser cows in Danish dairy herds: Risk factors. Prev. Vet. Med. 79:136-154.

Tine rådgivning (Tine Norwegian Dairies). 2009. Nøkkeltall (key numbers). http://medlem.tine.no/cf/nokkeltall.cfm Accessed July 29, 2009.

Tucker, C. B., and D. M. Weary. 2004. Bedding on geotextile mattresses: How much is needed to improve cow comfort? J. Dairy Sci. 87:2889-2895.

Valde, J. P., D. W. Hird, M. C. Thurmond, and O. Østerås. 1997. Comparison of ketosis, clinical mastitis, somatic cell count, and reproductive performance between free stall and tie stall barns in Norwegian dairy herds with automatic feeding. Acta Vet. Scand $38: 181-192$.

Wander, J. F. W. 1974. Zur Einrichtung von Liegeboxenställen für Milchkühe. Bauen auf dem Lande 5:138-141.

Wilmink, J. B. M. 1987. Comparison of different methods of predicticting 305-days milk yield means calculated from withinherd lactation curves. Livest. Prod. Sci. 17:1-17.

Wood, P. D. P. 1967. Algebraic model of the lactation curve in cattle. Nature 216:164-165.

Zdanowicz, M., J. A. Shelford, C. B. Tucker, D. M. Weary, and M. A. G. von Keyserlingk. 2004. Bacterial populations on teat ends of dairy cows housed in free stalls and bedded with either sand or sawdust. J. Dairy Sci. 87:1694-1701. 